\title{
Taxonomic studies on the Brachistini (Hymenoptera, Braconidae, Brachistinae) fauna of the eastern Anatolia region (Bingöl, Bitlis, Muş and Van) from Turkey
}

\author{
Ahmet Beyarslan a,*, Rukiye DEVECi ${ }^{b}$ \\ aBitlis Eren University, Faculty of Science and Arts, Department of Biology, TR-13000, Bitlis, Turkey \\ ${ }^{\mathrm{b}}$ Bitlis Eren University, Faculty of Science and Arts, Department of Biology, TR-13000, Bitlis, Turkey (Graduate student)
}

\begin{tabular}{l} 
A R T I C L E I N F O \\
\hline Article history: \\
Received 22 July 2019 \\
Received in revised form 21 October 2019 \\
Accepted 23 October 2019 \\
\hline Keywords: \\
Schizoprymnus \\
Polydegmun \\
Parasitoid \\
Malasie \\
Braconidae, \\
Yu \\
Tobias
\end{tabular}

\begin{abstract}
A B S T R A C T
In order to determine Braconidae fauna of Turkey, adult specimens of Braconidae (Hymenoptera) are collected from different habitats of Bingöl, Bitlis, Muş and Van provinces with using Malaise and light traps and sweeping nets between 2015 and 2019. The collected materials are prepared and labelled. In addition, appropriated literature are used for taxonomical examination of the obtained material. The altitudes and coordinates of localities and collection dates are presented. A total of 3 species in 2 genera of Brachistini are determined. From these species Foersteria polonoca Fahringer, 1934 is firstly record in the fauna of Turkey. However, Schizoprymnus (Schizoprymnus) bidentulus (Szépligeti, 1901) and S.(S.) elongatus (Szépligeti,1898) have been discovered. These two species are for the first records in the research area.
\end{abstract}

(C) 2019. Turkish Journal Park Academic. All rights reserved.

\section{Introduction}

Braconidae after Ichneumonidae is the second largest family of Hymenoptera (Aguiar et al., 2013) include more than 21,220 species under 1,100 genera of 45 subfamilies. Brachistini Foerster, 1863 is the largest tribe of Brachistinae Foerster, 1863 with 416 species under 11 genera (Yu et al., 2016). Almost all species of Brachistini are endoparasites of larvae of Coleoptera (van Achterberg, 1988) (especially on the families Curculionidae and Apionidae and about 25 other families of Coleoptera), which also include very important agricultural pests. Some species of Brachistini are very well known to be egg-larval parasitoids and this habit may prevail throughout the tribe (Shaw and Huddleston, 1991).

Brachistinae is certainly close to Helconinae and is always considered as its tribe (van Achterberg, 1990; Shaw and Huddleston, 1991). However, the 2nd radiomedial vein on the forewing of Brachistins absent and the body is small (2$2.5 \mathrm{~mm}$ ). It is distinguished by a clearly manifest tendency for the fusion of the first few abdominal tergites into a shield (Tobias, 1986). Brachistini is distributed in 209 countries of Afrotropical, Australasian, Nearctic, Neotropical, Oceanic, Oriental and Palaearctic zoogeographic regions, and introduced into Columbia, Ontario, Florida, Louisiana, Mississippi, New Jersey and Texas for biological control (Yu et al., 2016).

The tribe Brachistini is recognizable by Propodeum dorsally carinate, and rugose all over; second analis (2A) not present in hindwing; Dorsope of first tergite absent (van Achterberg, 1993). The first three abdominal tergites separated; articulation between 1st and 2nd tergites movable Sternauli usually smooth (Tobias, 1986). In Brachistini there are only

\footnotetext{
* Corresponding author.

E-mail address: abeyarslan@beu.edu.tr
} 
two submarginal cells in the forewing, and the gaster is generally relatively short and broad (Shaw and Huddleston, 1991).

The tribe Brachistini Foerster, 1863, was already included in the subfamily Helconinae Foerster, 1863 (van Achterberg $1988,1990,2000)$, but because of recent results of DNA analyses (Belshaw et al., 2000) the tribe is treated by van Achterberg (2003a) as a subfamily, similarly as by Tobias (1986) and Belokobylskij (1998). Already the only recent key to the subfamilies of Braconidae was that published by Tobias (1986). This key contains 20 subfamilies and the Tribe Brachistini placed in the subfamily Brachistinae (Tobias (1986). This tribe is not well known in the Turkish fauna. Prior to this study, only on the Turkish Brachistini fauna was conducted six studies:

Three closely involved Palaearctic genera of the subtribe Brachistina, Foersteria Szépligeti, 1896, Polydegmon Foerster, 1863 and Chelostes van Achterberg, 1990 are revised and illustrated. The Holarctic genera of the Brachistina are keyed and from Turkey are described two new species. The genus Aliolus Say, 1836 is synonymized with the genus Eubazus Nees, 1814 (van Achterberg, 1990). A new species Schizoprymnus erzurumus Belokobylskij, Güçlü and Özbek, 2003 (Hymenoptera: Braconidae, Brachistinae) is described from Turkey (Belokobylskij, et al., 2003). A new species Chelostes subrobustus Yilmaz and Beyarslan, 2009 is described and the Chelostes species of the world are keyed by Yılmaz and Beyarslan (2009). Then Beyarslan (2011) has recorded a new species Eubazus (Brachistes) aydae Beyarslan, 2011 from the Turkish Thrace and Central Anatolia region and new species was described, its morphological diagnostic characters were illustrated. Totally 34 Brachistinae (Hymenoptera: Braconidae) species in 5 genera, in the Northeast Anatolian Region of Turkey during 1998-2006 were recorded and the hosts of Schizoprymnus arcuatus Tobias, 1986, S. nigripes and S. tentalus were obtained for the first time (Güçlü and Özbek, 2011) Seven Triaspis species have been reported from Turkey (Koldaş et al., 2018). The objective of this study as our ongoing research on the taxonomy of Brachistini is to improve our knowledge about the tribe Brachistini Foerster, 1863.

\section{Material and Methods}

Bingöl, Bitlis, Muş and Van provinces located in Turkey's Eastern Anatolia region. The area is mountainous and heterogeneous and generally hot and arid during the summer. The winter covers $55 \%$ of the year and is snowy and cold. Sampling was carried out by using sweeping-net from various habitats of the area between 2014 and 2019, Adult specimens of Brachistini were collected on grass-type plants to determine the Brachistini fauna of Turkey. The obtained materials were prepared. The dried specimens were then card-mounted and labelled with locality label. appropriated literature (van Achterberg, 1990, 2003a, 2003b; Belokobylskij, 1998; Beyarslan, 2011; Tobias, 1986; Yilmaz and Beyarslan, 2009) were used for taxonomical examination and identification of the specimens. The terminology of morphological characters follows van Achterberg (1993). Type material are deposited in the collection of Bitlis, Eren University, Faculty of Science and Art, Department of Biology

\section{Results}

In this study, the collected and prepared materials were carefully analyzed. A total of 3 species were identified under 2 genera. Foersteria polonoca Fahringer, 1934 is recorded for the first time in the fauna of Turkey.

\section{Subfamily: Brachistinae}

Tribe: Brachistini Foerster, 1863

Genus: Foersteria Szépligeti,1896

Foersteria polonoca Fahringer, 1934

Material examined: Bitlis, Nemrut Dağı, Kaldera, Ilık Göl, (Allium sp., Anchusa sp., Astragallus sp., Cyperus sp., Euphorbia sp., Hypericum sp., Juniperus sp., Quercus sp., Pinus sp.), (383' $\left.10^{\prime \prime} \mathrm{K}, 42^{\circ} 14^{\prime} 28^{\prime \prime} \mathrm{D}\right), 2485$ m. 18.06.2015, 2ㅇ, 17 o'; 07.06.2019, $2 \sigma^{\prime}$.

Diagnosis: Face coarsely transversely rugose and $0.88 \mathrm{x}$ as long as its wide;

antenna with 26 segments; first flagelomera as long as second; subapical antennal segments of female slender; ratios of ocular-ocellar line: diameter of posterior ocellus: postocellar line = 20: 5: 8; occipital carina complete; stematicum smooth and glabrous; apical rim of clypeus distinctly differentiated from remainder of clypeus; length of eye in dorsal view $0.76 \mathrm{x}$ temple and temples parallel-sided or slightly widened behind eyes; hind femur dark brown or infuscated, if completely yellowish then second metasomal tergite completely and densely rugose-reticulate; Length of mesosoma $1.45 \mathrm{x}$ its height; pronope not well visible; side of pronotum largely crenulate-rugose; mesosternal suture not developed; epicnemial area rugose-punctate dorsally; mesoscutal lobes, scutellar sulcus deep, wide; scutellum convex and largely smooth; surface of propodeum partly smooth anteriorly and with areolas; fore wing distance from apex of marginal cell of fore wing to apex of wing $0.54 \mathrm{x}$ vein $1-\mathrm{R} 1$; first discal cell not petiolate; r:3-SR+SR1:2-SR =6:48:14. Hind coxa distinctly rugose dorsally; ratios of femur: tibia: basitarsus of hind leg = 40: 48: 30; length of femur, tibia and basitarsus of hind leg 2.0, 2.5 and $0.75 \mathrm{x}$ their maximum width, respectively; Second metasomal tergite densely rugosereticulate; 3 rd tergite with very coarsely cellulate and protruding sculpture medioposteriorly; length of ovipositor sheath about $1.3 \mathrm{x}$ fore wing; hind femur with wide ventral carina, rugose and yellowishbrown; ventral carina of fore coxa distinct;

Host. Unknown

Distribution: Western Palaearctic. Hungary, Poland, Slovakia and Turkey (new record) (Yu et al., 2016).

New to Turkey.

Genus: Schizoprymnus Foerster,1863

Schizoprymnus (Schizoprymnus) bidentulus (Szépligeti, 1901) 
Material examined: Bitlis, Ahlat, Abdurrahmangazi, (Allium sp., Anchusa sp., Astragallus sp., Cyperus sp., Hypericum sp.) $\left(38^{\circ} 45^{\prime} 27^{\prime \prime} \mathrm{N}, 42^{\circ} 31^{\prime} 41^{\prime \prime} \mathrm{E}\right), 1649$ m. 18.06.2015 1 \%. Bitlis, Hizan, Gayda district, ( Anchusa sp., Astragallus sp., Hypericum sp., Juniperus sp., Quercus sp., Pinus sp.), (38 10'34.4892"K, 42。 23' 29.9184"D), 1257 m. 13.06.2015, ơ. Bitlis, TatvanHizan 15. km, (Anchusa sp., Astragallus sp., Cyperus sp., Hypericum sp.) (38²6'14'K, 42¹9'17'D), $1790 \mathrm{~m}$. 13.06.2015, 2\%. Bitlis, Hizan, Trout facilities, (Anchusa sp., Astragallus sp., Cyperus sp., Hypericum sp.) (38 26'14"K, 42¹9'17'D), 1790 m. 19.06.2015, o'. Bitlis, Tatvan, Police camp, (Allium sp., Anchusa sp., Astragallus sp., Hypericum sp.) (38³7'23'"K, 42²5'01'D), 1688 m. 15.07.2015, o'.

Diagnosis: Head behind eyes somewhat roundly narrowed, temples usually not longer than eye; Antennae longer with greater number of segments (usually 22-segmented); clypeus large, not more than 0.5 as high as wide; tentorial pits wide set, intertentorial line not more $1.5 x$ longer than tentoriocular line; body short, less well proportioned; abdominal shield at apex not bent under, abdominal shield short oval, distinctly convex; apically lacking lamellar projections and with 2 large obtuse denticles; radial cell not shorter than stigma; denticles on propodeum fairly acute; legs in greater part black, apices of femora yellowish dark brown; body $2.25 \mathrm{~mm}$.

Host: Unknown.

Distribution: Palaearctic. Armenia, Bulgaria, Czechoslovakia, Hungary, Kazakhstan, Spain, Turkey (Güçlü and Özbek, 2011) and Yugoslavia (Yu et al., 2016).

\section{Schizoprymnus (Schizoprymnus) elongatus (Szépligeti, 1898) (syn.angustissimus (Snof.)}

Material examined: West entrance of Van Erciș, (Anchusa sp., Cyperus sp., Euphorbia sp., Juniperus sp., Pinus sp., Salix sp., Populus sp.), (39²' 2.2632"K, 43 19' 43.1436"D), 1695 m., 28.7.2016, ᄋ. Bitlis, Ahlat, Abdurrahmangazi, (Allium sp., Anchusa sp., Astragallus sp., Cyperus sp., Hypericum sp.), (3845'27"N, 42³1'41"E), 1649 m., 19.6.2015, o'.

Diagnosis: Head above densely punctate, matte, lustrous and behind eyes somewhat roundly narrowed; in dorsal view temples $0.75 \mathrm{x}$ as long as eye; Antennae longer with greater number of segments; clypeus large, much narrower than width of face, $2.0 \mathrm{x}$ as long as its wide; tentorial pits wide set, intertentorial line not more 2.0x than tentorioocular line; Body long, well proportioned, abdominal shield at apex not bent under ; abdominal shield longitudinally oval, apically lacking lamellar projections; radial cell longer than pterostigma (6:5); propodeum lacking denticles; legs in greater part black dark brown; apices of femora, tibia and Tarsus yellowish; Body $3.60 \mathrm{~mm}$.

Host: Unknown.

Distribution: Palaearctic. Afghanistan, Armenia, Azerbaijan, Czech Republic, Czechoslovakia, Georgia, Kazakhstan, Lithuania, Moldova, Turkey (Güçlü and Özbek, 2011).

\begin{abstract}
4. Conclusions
Three species from 2 genera were identified with the taxonomic studies conducted on Brachistinae (Hymenoptera, Braconidae) Fauna of Bingöl, Bitlis, Muş and Van. All of these species are the first record for the study field. The species Foersteria polonoca is the new record for the fauna of Turkey. The general distribution of the detected species was revealed. The general distribution of Foersteria polonoca is limited to 3 country of Western Palaearctic region. Schizoprymnus (Schizoprymnus) bidentulus is distributed in 8 countries of the Palaearctic region and S. (S.) elongatus is distributed in 11 countries of the same region. Almost all species of Brachistini are endoparasites of larvae of Curculionidae and Apionidae and about 25 other families of Coleopter in addition (Coleoptera) (van Achterberg, 1988) which also include very important agricultural pests. Some species of Brachistini are very well known to be egg-larval parasitoids and this habit may prevail throughout the tribe (Shaw and Huddleston, 1991). But, hosts of these three species which have parasitoid lifestyle are not known. Biology of these species should be studied and biological control features should be revealed.
\end{abstract}

\section{Acknowledgements}

The tools used in this research were provided by the Scientific Research Project Unit of Bitlis Eren University. (BEBAP Projects 2016.06 and 2019.01). We would like to thank this institution for its financial supports.

\section{References}

Achtenberg van, C., 1988. Revision of the subfamily Blacinae Foerster (Hymenoptera, Braconidae). Zool. Verh. Leiden 249: 1-324.

Achtenberg van, C., 1990. Revision of the genera Foersteria Szépligeti and Polydegmon Foerster (Hymenoptera: Braconidae) with the description of a new genus. Zool. Verh. Leiden, 257: 1-32.

Achterberg van, C., 1993. Illustrated key to the subfamilies of the Braconidae Hymenoptera: Ichneumonoidea). Zool. Verh. 283: 1-189.

Achterberg van, C. 2000. The European species of the Eubazus aliochinoi-group (Hymenoptera: Braconidae: Helconinae: Brachistini). Zool. Med. Leiden; 74: 339-357.

Achterberg van, C., 2003a. The European species of the subgenus Aliolus Say of the genus Eubazus Nees and of the genus Dicyrtaspis van Achterberg (Hymenoptera: Braconidae: Brachistinae). Zool. Med. Leiden, 77 (17): 1-53 (30.xii.2003: 301-320, ISSN 0024-0672.

Achterberg van, C., 2003b. The European species of the Eubazus aliochinoi-group (Hymenoptera: Braconidae: Helconinae: Brachistini). Zool. Med. Leiden 2000; 74: 339-357.

Aguiar, A., Deans, A.R., Enge,l M.S., Forshage, M., Huber, J.T., Jennings, J.T., Johnson, N., Lelej, A.S., Longino, J.T., Lohrmann, V., Miko, I., Ohl, M., Rasmussen, C., Taeger, A., Yu, D.S.K., 2013. Order Hymenoptera. Zootaxa 3703(1), 5162.

Belokobylskij, S.A., 1998. 12. Podsem. Brachistinae (Calyptinae): 440489. In: P.A. Ler (ed.). Opredelitel nasekomych dalnego vostoka Rossii (4)3: 1-708. - Vladivostok. 
Belokobylskij, S.A., Güçlü, C., Özbek, H., 2004. A new species of the genus Schizoprymnus Foerster from Turkey (Hymenoptera: Braconidae, Brachistinae)". Zoosystematica Rossica. 12: 245-248.

Belshaw, R., Dowton, M., Quicke, D.L.J., Austin, A.D., 2000. Estimating ancestral geographic distributions: A Gondwanan origin for aphid parasitoids? Proc. R. Soc. Lond. B 267 (1442): 491-496. DOI 10.1098/rspb.2000.1027

Beyarslan, A., 2011. "Eubazus (Brachistes) aydae sp. nov. from Turkey (Hymenoptera: Braconidae: Brachistinae). Journal of the Entomological Research Society. 13 (1): 107-111.

Güçlü, C., Özbek, H., 2011. "A Contribution to the Knowledge of the Subfamily Brachistinae (Hymenoptera: Braconidae) in Turkey J.Entomol. Res. Soc., vol 13, no. 3, pp. 15-26,

Koldaș,T., Cetin Erdoğan, Ö., Beyarslan, A., 2018. Taxonomic and Faunistic Data on the Genus Triaspis Haliday, 1835 (Hymenoptera: Braconidae: Brachistinae) from Turkey. World Academy of Science, Engineering and Technology International Journal of Biological and Ecological Engineering 12 (11): 424-429.

Shaw, M.R., Huddleston, T., 1991. Classification and biology of Braconid wasps (Hymenoptera: Braconidae). Royal Entomological
Society of London, 7(11): 1-126

Tobias, V.I., 1986. Subfam. Brachistinae (Calyptinae), pp. 150-180. In: Medvedev G.S. (ed.), Opredelitel' nasekomykh Evrospe ısko ı chasti SSSR 3, Pereponchatokrylye. Vol. 3. [Keys to Insects of the Euroepan part of the USSR. Hymenoptera].Nauka, Leningrad.

Yilmaz, T., Beyarslan, A., 2009. "A new species of Chelostes van Achterberg, 1990 (Braconidae: Brachistinae) from Turkey". Biologia, 64(2: 340-342.

Yu, D.S., Achterberg van, C, Horstmann, K., 2016.World Ichneumonoidea 2004. Taxonomy, Biology, Morphology and Distribution (Braconidae). Taxapad 2005; (Scientific Names for Information Management) Interactive Catalogue on DVD/ CDROM. Vancouver. 